\title{
Çocuklarda Kortikal Gelişimsel Malformasyonlara Tanısal Yaklaşım: 36 Hastanın Klinik, Görüntüleme ve Laboratuvar Verileri
}

\author{
Diagnostic Approach of Malformations of Cortical Development in \\ Children: Data of Clinical, Laboratory, and Imaging of 36 Patients
}

Cengiz HAVALI' ${ }^{1}$, Derya BAKO²

'Sağlık Bilimleri Üniversitesi, Bursa Yüksek Intisas Eğitim ve Araştırma Hastanesi, Çocuk Sağlığı ve Hastalıkları Anabilim Dalı,

Çocuk Nöroloji Bilim Dalı, Bursa, Türkiye

2Sağlık Bilimleri Üniversitesi, Van Eğitim ve Araştırma Hastanesi, Çocuk Radyoloji Bilim Dalı, Van, Türkiye

\section{Öz}

Amaç: Kortikal gelişimsel malformasyonlar (KGM) nöronal hücrelerin gelişimi, göçü ve yerleşim evrelerinde görülen bozukluklar nedeniyle ortaya çıkan ve nadir görülen santral sinir istemi anomalileridir. Etyoloji, eşlik edebilen diğer nörolojik ve sistemik durumlar nedeniyle oldukça heterojen fenotip çeşitliliğe sahip olan KGM, en sık olarak nöbet, motor ve bilişsel gerilik bulgularından bir veya birkaçının bir arada bulunduğu tablo ile ortaya çıkar.

Gereç ve Yöntemler: Son beş yıl içinde KGM tanısı alan 36 hastanın klinik, laboratuvar, elektrofizyolojik ve görüntüleme bulguları sunulmuştur. Genetik testlerle kesin mutasyon gösterilebilen hastaların fenotipi, epilepsisi olan hastalarda ilaç yanıtları gözden geçirilmiştir.

Bulgular: Hastaların en sık başvuru nedeninin motor ve bilişsel gerilik olduğu ve \%72 hastada nöbetlerin eşlik ettiği saptandı. Hastaların üçte birinde tüm beyin loblarını tutan yaygın KGM, üçte ikisinde bir ya da birden çok lobu içeren malformasyon olduğu görüldü. Genetik mutasyonu gösterilen sekiz hastanın yarısında saptanmış olan konjenital müsküler distrofi en sık saptanan genetik tanılı durumdu. Hastaların tümünde KGM görüntüleme yöntemleriyle saptandı.

Sonuç: Oldukça geniş bir etyolojiye sahip olan nöbetler, motor ve bilişsel geriliğin bir arada olduğu klinik ile başvuran hastalarda görüntüleme yöntemleriyle saptanmış olan KGM'nin tipi, yaygınlığı, eşlik eden diğer santral sinir sistemi anormallikleri ve muayene bulguları tanı aşamasında yol göstericidir. Tüm bulgular bir arada değerlendirilerek bir sonraki aşamada yapılacak testler belirlenmelidir. Genetik bilimindeki gelişmeler, yeni teknikler ve yaygınlaşan test imkânları bu hastalıkların tanısı, tedavi seçenekleri ve prognozlarının öngörülmesinde ve genetik danışma ve planlamalar açısından önemli katkılar sağlamaktadır.

Anahtar Sözcükler: Epilepsi, Kortikal gelişim malformasyonlar, Motor ve bilişsel gerilik

\begin{abstract}
Objective: Malformations of cortical development (MCD) are rare central nervous system abnormalities that are caused by disruption of normal cortical development stages, including neural cell proliferation, cell type differentiation, neuronal migration, and final neuronal positioning. It has different phenotypic presentations which largely depend on the underlying cause of the disorder and is associated with other neurologic and systemic disorders. MCD frequently present with seizures, various degrees of developmental delay, and intellectual disability.
\end{abstract}

\begin{abstract}
(1)
HAVALI C : :0000-0001-6275-0884 BAKO D : :000-0003-0642-6793

Çıkar Çatışması / Conflict of Interest: Tüm yazarlar adına, ilgili yazar çıkar çatışması olmadığını belirtir.

Etik Kurul Onayı / Ethics Committee Approval: Araștırma için Sağlık Bilimleri Üniversitesi, Bursa Yüksek Ihtisas Eğitim ve Araștırma Hastanesi etik kurulundan 2011-KAEK-25 2021/03-09 sayı numarası ile onay alındı.

Yazarların katkısı / Contribution of the Authors: HAVALI C: Araștırma ve/veya makalenin hipotezini veya fikrini olușturan, Sonuçlara ulașmak için planlama/ metodoloji belirleme, Araştırma/çalışmanın sorumluluğunu üstlenmek, ilerlemenin seyrini denetlemek, Hasta takibinde sorumluluk almak, ilgili biyolojik malzemelerin toplanması, veri yönetimi ve raporlama, deneylerin yürütülmesi, Sonuçların mantıksal olarak Yorumlanması ve sonuçlandırıması, Calıșma için gerekli literatür taramasında sorumluluk almak, Çalıșmanın bütününün veya önemli bölümlerinin yazımında sorumluluk almak, Yazım ve dilbilgisi dıșında bilimsel olarak gönderilmeden önce makaleyi gözden geçirme. BAKO D: Araştırma ve/veya makalenin hipotezini veya fikrini oluşturan, Sonuçlara ulaşmak için planlama/metodoloji belirleme, Sonuçların mantıksal olarak Yorumlanması ve sonuçlandırıması, Çallşma için gerekli literatür taramasında sorumluluk almak, Çalışmanın bütününün veya öneml bölümlerinin yazımında sorumluluk almak, Yazım ve dilbilgisi dışında bilimsel olarak gönderilmeden önce makaleyi gözden geçirme.

Atıf yazım șekli / How to cite : Havalı C ve Bako D. Çocuklarda Kortikal Gelişimsel Malformasyonlara Tanısal Yaklaşım: 36 Hastanın Klinik, Görüntüleme ve Laboratuvar Verileri. Türkiye Çocuk Hast Derg 2021;15:365-372.
\end{abstract}

Yazıșma Adresi / Correspondence Address:

\section{Cengiz HAVALI}

Sağlık Bilimleri Üniversitesi, Bursa Yüksek İhtisas Eğitim ve Araștırma Hastanesi,

Çocuk Sağlığı ve Hastalıkları Anabilim Dalı, Çocuk Nöroloji Bilim Dalı, Bursa, Türkiye

E-posta: cengizhavali@gmail.com
Geliş tarihi/ Received : :05.04.2021 Kabul tarihi / Accepted : 28.05.2021 Elektronik yayın tarihi : 10.09 .2021 Online published

DOI: $10.12956 /$ tchd.899026 
Material and Methods: The findings of clinical, laboratory, electrophysiological, and magnetic resonance imaging of thirty-six patients diagnosed with MCD in the last five years have been reported. Responses to drug therapies in epileptic patients and phenotypic expressions in patients with the genetically proved mutation were also reviewed.

Results: Developmental delay, intellectual disability, and seizures (\%72) were the main clinical findings. MCD has been recognized with magnetic resonance imaging in all patients. Diffuse cortical malformations have been detected in a third of our patients. Single and/or multiple brain lobe involvements have been determined in other patients. Congenital muscular dystrophy was the most diagnosed disease in the patients who had elucidated with genetic tests.

Conclusion: Seizures, developmental delay, and intellectual disability could be caused by many disorders including MCD. The type and diffusiveness of the MCD, associated neurologic and systemic findings should be accurately evaluated. Recent developments in genetic methods have improved the accurate diagnosis, prognosis prediction, and treatment planning strategies in patients with MCD.

Key Words: Epilepsy, Malformations of cortical development, Motor and cognitive retardation

\section{GiRiş}

Serebral korteksin oluşumu intrauterin 8. haftada başlayarak 24. haftada altı katmanlı yapısına ulaşır. Giral yapıların matür insan beynindeki yapısına ulașması postnatal birkaç aya kadar devam ederken, aksonların miyelinize olması, sinaptik bağların olgunlaşması bu aşamadan sonra sürmektedir. Serebral korteksin gelişimi, karmaşık ve sıkı bir şekilde düzenlenen ve yer yer iç içe geçen üç ana aşamadan oluşur. Nöral kök hücre proliferasyonu ve farklılaşması, nöronal migrasyon ve yerleşme, nöronların ileri kortikal organizasyonu ve nöronlar arası bağlantı oluşumları temel basamaklardır. Bu süreçlerin bir ya da birkaçında oluşan aksaklıklar, geniş bir yelpazesi bulunan kortikal gelişimsel malformasyonlara (KGM) neden olur (1). KGM genetik, enfeksiyöz, vasküler ve metabolik nedenlere bağlı olarak ortaya çıkabilir (2). Anormal kortikal yapı şeklinde görülebileceği gibi heterotopik gri cevher yapılarının anormal lokalizasyonu ile kendini gösterebilir. Her yașta bulgu verebilen KGM, epilepsi, gelişimsel gerilikler, bilişsel gerilik ve motor gelişim basamaklarında geriliklerin bir ya da birkaçının bir arada olduğu oldukça heterojen bir klinik çeşitlilik gösterir (3).

KGM radyolojik görüntüleme yöntemleriyle gösterilebilir ve tanımlanabilir. Bu aşamadan sonra klinik fenotip, eşlik eden diğer organ tutulumları ve kortikal malformasyonun tipine göre etyoloji araştırıı (4). Pakigri, lizensefali, kaldırım taşı (cobblestone) lizensefali, polimikrogri, şizensefali, subkortikal band heterotopi, periventriküler heterotopi, fokal kortikal displazi temel nöropatolojik KGM tipleridir (5). Birçok spesifik genetik neden tanımlanmış olmakla birlikte, bazı mitokondrial ve peroksizomal hastalıklar, bazı konjenital müsküler distrofiler, intrauterin enfeksiyonlar KGM ile bulgu verebilir.

Bu çalışmada, KGM saptanan 36 hastanın klinik, radyolojik ve genetik verileri sunulmuştur.

\section{GEREÇ ve YÖNTEMLER}

Son beş yıl içinde motor ve/veya bilişsel gelişme geriliği, epilepsi nedeniyle araştırılan veya başka nedenlerle yapılan görüntüleme esnasında KGM tanısı alan çocuk hastaların; demografik verileri, klinik bulguları, beyin manyetik rezonans görüntüleme (MRG) bulguları, elektroensefalografi (EEG) bulguları (18 kanallı, en az 20 dakikalık uyanık ve/veya uyku durumunda) ve genetik analiz sonuçları retrospektif olarak incelendi. Araştırma için Sağlık Bilimleri Üniversitesi, Bursa Yüksek İhtisas Eğitim ve Araştırma Hastanesi etik kurulundan 2011-KAEK-25 2021/03-09 sayı numarası ile onay alınd..

\section{BULGULAR}

KGM tanısı ile izlenen 16'sı erkek, 20'si kız 36 hasta değerlendirilmiştir. Hastaların yaş ortalaması 6.9 yıl (en küçük: iki ay, en büyük 17 yıl) olarak bulundu. Hastaların ortalama takip süreleri 22.8 ay (0-62)'di. Dört hasta ilk muayeneleri sonrası takip edilemedi.

Otuz hasta (\%83) motor ve/veya bilişsel gerilik ile dört hasta (\%11) sadece nöbet ve iki hasta (\%6) baş ağrısı ve baş dönmesi şikâyetiyle başvurdu. Yirmi bir hastada (\%58) motor ve bilişsel gerilik bir arada bulunmaktaydı. Yirmi yedi hastada (\%75) klinik bulgular içinde nöbetler mevcutken kalan dokuz hastada (\%25) başvuru esnasına kadar olan dönemde ve takip süresince nöbet görülmedi. En sık rastlanan ana başvuru nedenleri olan motor gerilik, bilişsel gerilik ve nöbetlere sadece iki hastada (\%6) rastlanmadı. Bu iki hasta baș ağrısı ve baș dönmesi nedeniyle başvuran ve sadece nodüler heterotopi saptanan hastalardı.

Yirmi sekiz hastada (\%78) bilişsel becerilerde yaşına göre gerilik mevcuttu. Altı hastanın (\%17) bilişsel becerileri yaşına göre normalken iki hastada(\%6) yaşına uygun bilişsel testlere ulaşılamadı. Yirmi altı (\%72) hastada ise motor becerilerde yaşına göre gerilik saptand. On hastada motor becerilerde gerilik saptanamadı.

Yirmi altı hastada (\%72) KGM'ye epilepsi eşlik etmekteydi. Nöbeti olmayan 10 (\%28) hastanın 2'sinde izole periventriküler nodüler heterotopi, üçünde fokal KGM, beşinde ise tüm lobları içeren yaygın KGM mevcuttu. Takipte oldukları süre içinde nöbeti olan 26 hastanın, 13'ünde bir ilaçla, beşinde iki ilaçla, ikisinde üç ve birinde dört ilaçla nöbetler kontrol altına alınabildi. Bir hastanın dört ilaca rağmen yılda birkaç kez nöbetleri olmaya devam etti. Üç hastanın takip süreleri yetersiz olduğundan nöbet kontrolü konusunda bilgiye ulaşılamazken bir hasta erken dönemde kaybedildi. 
Tablo I: Hastaların demografik, klinik, laboratuvar ve görüntüleme sonuçları.

\begin{tabular}{|c|c|c|c|c|c|c|c|c|c|c|}
\hline & Yaş/C & MG & BG & $\begin{array}{l}\text { EEG epileptik } \\
\text { deşarj sıklığı }\end{array}$ & MRG & $\begin{array}{c}\text { KGM } \\
\text { sınıflama }\end{array}$ & Nöbet & Genetik/tanı & $\begin{array}{c}\text { Takip } \\
\text { süresi } \\
\text { (ay) }\end{array}$ & Ek tutulum \\
\hline 1 & $10 \mathrm{y} / \mathrm{e}$ & - & + & $\mathrm{N}$ & $\begin{array}{l}\text { Sol f, t, p, polimikrogri, } \\
\text { pakigri, heterotopi }\end{array}$ & 2,3 & $\begin{array}{c}+ \\
1 \text { ilaçla } \\
\text { kontrol }\end{array}$ & - & 2 & - \\
\hline 2 & $4 \mathrm{y} / \mathrm{k}$ & + & + & $\begin{array}{c}\text { Bilateral f 2-3 sn } \\
\text { aralarla, 0.2-3 sn } \\
\text { süreli }\end{array}$ & $\begin{array}{c}\text { Bilateral şizensefali dev } \\
\text { giriform heterotopi (beyin } \\
\text { içinde beyin) }\end{array}$ & 2,3 & $\begin{array}{c}+ \\
1 \text { ilaçla } \\
\text { kontrol }\end{array}$ & - & 24 & $\begin{array}{l}\text { Görme kaybı, } \\
\text { lökokori, } \\
\text { mikrokornea, } \\
\text { hidrosefali, } \\
\text { v-p şant }\end{array}$ \\
\hline 3 & $13 \mathrm{y} / \mathrm{k}$ & + & + & $\mathrm{N}$ & $\begin{array}{l}\text { Yaygın lizensefali, } \\
\text { subkortikal band } \\
\text { heterotopi }\end{array}$ & 2,3 & $\begin{array}{c}+ \\
1 \text { ilaçla } \\
\text { kontrol }\end{array}$ & & 48 & - \\
\hline 4 & $3 \mathrm{y} / \mathrm{k}$ & + & + & $\mathrm{N}$ & $\begin{array}{c}\text { Sağ perisilvian pakigri, kk } \\
\text { disgenezisi. }\end{array}$ & 2 & - & & 2 & $\begin{array}{l}\text { Hidrosefali, } \\
\text { v-p şant }\end{array}$ \\
\hline 6 & $10 \mathrm{y} / \mathrm{k}$ & - & - & $\begin{array}{l}\text { Sağ t 5-10 sn } \\
\text { aralarla 0.5-3 sn } \\
\text { süreli }\end{array}$ & $\begin{array}{l}\text { Sol t, p, polimikrogri, } \\
\text { pakigri }\end{array}$ & 2,3 & $\begin{array}{c}+ \\
1 \text { ilaçla } \\
\text { kontrol }\end{array}$ & - & 17 & - \\
\hline 7 & $4 \mathrm{y} / \mathrm{k}$ & + & + & - & $\begin{array}{l}\text { Sağ Şizensefali, f, p } \\
\text { pakigri, polimikrogri }\end{array}$ & 2,3 & - & - & 12 & - \\
\hline 8 & $7 \mathrm{y} / \mathrm{e}$ & + & + & - & Yaygın basit giral yapı & 2 & $\begin{array}{c}+ \\
4 \text { ilaç, } \\
\text { yılda } \\
\text { birkaç } \\
\text { kez }\end{array}$ & $\begin{array}{c}\text { SRPX2 } \\
\text { Omim: } 300643 \\
\text { NM(014467) c.1237C>T } \\
\text { p.(Arg413Cys)Homozigot: } \\
\text { yeni mutasyon } \\
\text { Missense }\end{array}$ & : & $\begin{array}{l}\text { Mikrosefali, } \\
\text { korneal } \\
\text { bulanıklık }\end{array}$ \\
\hline 11 & $5 \mathrm{y} / \mathrm{k}$ & + & + & $\begin{array}{l}\text { Jen.5-15 sn } \\
\text { aralarla 1-2 Hz, } \\
\text { 1-2 sn süreli }\end{array}$ & $\begin{array}{l}\text { Yaygın lizensefali, } \\
\text { subkortikal band } \\
\text { heterotopi }\end{array}$ & 2 & $\begin{array}{c}+ \\
2 \text { ilaçla } \\
\text { kontrol }\end{array}$ & $\begin{array}{c}\text { PAFAH1B1 } \\
\text { omim: 607432 } \\
\text { (NM_000430)Varyant: } \\
\text { p.Arg371* (c.1111C>T) } \\
\text { Heterozigot bildirilmiş } \\
\text { variant } \\
\text { Nonsense }\end{array}$ & 48 & $\begin{array}{l}\text { Mikrosefali, } \\
\text { nistagmus+ }\end{array}$ \\
\hline 12 & $15 \mathrm{y} / \mathrm{k}$ & - & + & $\mathrm{N}$ & $\begin{array}{l}\text { Bilateral pv nodüler } \\
\text { heterotopi }\end{array}$ & 2 & $\begin{array}{c}+ \\
1 \text { ilaçla } \\
\text { kontrol }\end{array}$ & & 3 ay & \\
\hline 13 & $5 \mathrm{y} / \mathrm{k}$ & + & - & $\begin{array}{l}\text { Sağ sp 1-3 sn } \\
\text { aralarla, 0,5-2 sn } \\
\text { süreli }\end{array}$ & $\begin{array}{l}\text { Sağ f, t, p, pakigri, } \\
\text { polimikrogri }\end{array}$ & 2,3 & $\begin{array}{c}+ \\
2 \text { ilaçla } \\
\text { kontrol }\end{array}$ & & 51 & Sol hemiparezi \\
\hline 14 & $15 \mathrm{y} / \mathrm{e}$ & - & - & $\mathrm{N}$ & Sol pv nodüler heterotopi & 2 & $\begin{array}{c}+ \\
1 \text { ilaçla } \\
\text { kontrol }\end{array}$ & - & 9 & - \\
\hline 15 & $7 \mathrm{y} / \mathrm{k}$ & + & + & - & $\begin{array}{l}\text { Bilateral t, p, oks, loblar } \\
\text { ve f vertekste lizensefali, } \\
\text { Subkortikal heterotopi }\end{array}$ & 2,3 & - & & 0 & \\
\hline
\end{tabular}




\begin{tabular}{|c|c|c|c|c|c|c|c|c|c|c|}
\hline & Yaş/C & MG & BG & $\begin{array}{l}\text { EEG epileptik } \\
\text { deşarj sıklığı }\end{array}$ & MRG & $\begin{array}{c}\text { KGM } \\
\text { siniflama }\end{array}$ & Nöbet & Genetik/tanı & $\begin{array}{l}\text { Takip } \\
\text { süresi } \\
\text { (ay) }\end{array}$ & Ek tutulum \\
\hline 16 & $6 \mathrm{y} / \mathrm{k}$ & + & + & $\begin{array}{l}\text { Serebral } \\
\text { disfonksiyon }\end{array}$ & $\begin{array}{l}\text { Global pakigri, } \\
\text { polimikrogri, pv boşluklar }\end{array}$ & 2,3 & - & $\begin{array}{l}\text { GPR56 } \\
\text { omim: } 606854 \\
\text { (NM_001145770) } \\
\text { p.GIn300* (c.898C>T) } \\
\text { Homozigot yeni mutasyon } \\
\text { Nonsense }\end{array}$ & 61 & - \\
\hline 17 & $2 y / e$ & + & + & Hipsaritmi & $\begin{array}{l}\text { Yaygın lizensefali, } \\
\text { subkortikal band } \\
\text { heterotopi }\end{array}$ & 2 & $\begin{array}{l}\text { İnfantil } \\
\text { spazm } \\
1 \text { ilaç } \\
\text { nöbet } \\
\text { kontrolü } \\
?\end{array}$ & - & 20 & \\
\hline 18 & $3 y / e$ & + & - & $\mathrm{N}$ & Bilateral st pakigri & 2 & - & $\begin{array}{l}\text { POMGNT1 } \\
\text { WWS/MEB } \\
\text { (NM_001243766) } \\
\text { p.Gly505Ser (c.1513G>A) } \\
\text { Homozigot bildirilmiş } \\
\text { Missense }\end{array}$ & 24 & \\
\hline 19 & $2 \mathrm{y} / \mathrm{e}$ & + & + & - & $\begin{array}{l}\text { Yaygın lizensefali, } \\
\text { subkortikal band } \\
\text { heterotopi }\end{array}$ & 2 & - & & 14 & \\
\hline 20 & $3 y / e$ & + & + & - & $\begin{array}{l}\text { Yaygın girasyon } \\
\text { kaybı, polimikrogri. } \\
\text { dismiyelinizasyon, beyin } \\
\text { sapı hipoplazisi }\end{array}$ & 2,3 & - & & 0 & Görme kaybı \\
\hline 21 & $6 \mathrm{y} / \mathrm{k}$ & + & + & $\begin{array}{l}\text { Sağ f 2-4 sn } \\
\text { aralarla, 2-3 sn } \\
\text { süreli }\end{array}$ & Sağ f, p kortikal displazi & 1 & $\begin{array}{c}+ \\
3 \text { ilaçla } \\
\text { kontrol }\end{array}$ & - & 12 & \\
\hline 22 & $14 \mathrm{y} / \mathrm{k}$ & - & - & $\mathrm{N}$ & $\begin{array}{l}\text { Sağ anterior pv } \\
\text { heterotopi }\end{array}$ & 2 & - & 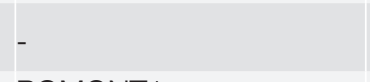 & 36 & - \\
\hline 23 & $5 \mathrm{y} / \mathrm{e}$ & + & + & - & $\begin{array}{l}\text { Yaygın girasyon kaybı } \\
\text {,pakigri dismiyelinizasyon, } \\
\text { beyin sapı hipoplazisi }\end{array}$ & 2 & - & $\begin{array}{l}\text { POMGNT1 } \\
\text { WWS/MEB } \\
\text { (NM_001243766) c.1111- } \\
\text { 1G>A Homozigot } \\
\text { Yeni mutasyon Splicing }\end{array}$ & - & \\
\hline 24 & $5 \mathrm{y} / \mathrm{k}$ & + & + & $\begin{array}{l}\text { Bilateral oks 2-6 } \\
\text { sn aralarla, 0,2-2 } \\
\text { sn süreli, }\end{array}$ & Yaygın polimikrogri & 3 & $\begin{array}{c}+ \\
2 \text { ilaçla } \\
\text { kontrol }\end{array}$ & $\begin{array}{l}\text { POMGNT2 WWS/MEB } \\
\text { (NM_032806) } \\
\text { lle264Ser(c.791T>C) } \\
\text { homozigot p.lle264Ser } \\
\text { Yeni mutasyon }\end{array}$ & 8 & $\begin{array}{l}\text { Görme kaybı } \\
\text { CK: } 3615\end{array}$ \\
\hline 25 & 2 ay/e & + & + & - & Bilateral f, t polimikrogri & 3 & $\stackrel{+}{+}$ & $\begin{array}{l}\text { PEX1 } \\
\text { ZS } \\
\text { (NM-000466)geninde } \\
\text { p.Leu597Pro(c.1790T>C) } \\
\text { homozigot } \\
\text { Yeni mutasyon }\end{array}$ & 1 & renal kistler \\
\hline 26 & $14 \mathrm{y} / \mathrm{k}$ & - & - & - & $\begin{array}{l}\text { Sağ ft pakigri, pv } \\
\text { heterotopi + }\end{array}$ & 2,3 & - & - & 0 & - \\
\hline 27 & $4 \mathrm{y} / \mathrm{k}$ & + & $?$ & $\begin{array}{l}\text { Sol f } 2-5 \text { sn } \\
\text { aralarla 1-2 sn } \\
\text { süreli }\end{array}$ & $\begin{array}{l}\text { Sol hemisfer } \\
\text { korteks düzensiz, } \\
\text { emimegalensefali+ kk } \\
\text { dismorfik }\end{array}$ & 1 & $+?$ & - & 1 & Sağ hemiparezi \\
\hline 28 & $4 \mathrm{y} / \mathrm{k}$ & - & - & $\begin{array}{l}\text { Bilateral ft 5-20 } \\
\text { sn aralarla 1-3 sn } \\
\text { süreli }\end{array}$ & Sağ t fkd & 1 & $\begin{array}{c}+ \\
1 \text { ilaçla } \\
\text { kontrol }\end{array}$ & - & 61 & - \\
\hline 29 & $8 \mathrm{y} / \mathrm{k}$ & + & + & $\begin{array}{l}\text { Sağ st 2-3 sn } \\
\text { aralarla, 1-2 sn } \\
\text { süreli }\end{array}$ & $\begin{array}{l}\text { Sağ f şizensefali, } \\
\text { heterotopi, d-w } \\
\text { formasyonu }\end{array}$ & 2,3 & $\begin{array}{c}+ \\
1 \text { ilaçla } \\
\text { kontrol }\end{array}$ & - & 48 & $\begin{array}{l}\text { Hidrosefali, } \\
\text { v-p şant }\end{array}$ \\
\hline
\end{tabular}




\begin{tabular}{|c|c|c|c|c|c|c|c|c|c|c|}
\hline & Yaş/C & MG & BG & $\begin{array}{l}\text { EEG epileptik } \\
\text { deşarj sıklığı }\end{array}$ & MRG & $\begin{array}{c}\text { KGM } \\
\text { sınıflama }\end{array}$ & Nöbet & Genetik/tanı & $\begin{array}{l}\text { Takip } \\
\text { süresi } \\
\text { (ay) }\end{array}$ & Ek tutulum \\
\hline 30 & $3 \mathrm{y} / \mathrm{k}$ & + & + & $\begin{array}{l}\text { Bilateral st 2-4 } \\
\text { sn aralarla, 1-3 } \\
\text { sn süreli }\end{array}$ & $\begin{array}{l}\text { Sağ f pakigri, polimikrogri } \\
\text { ve pv nodüler heterotopi }\end{array}$ & 2,3 & $\begin{array}{c}+ \\
2 \text { ilaçla } \\
\text { kontrol }\end{array}$ & - & 36 & \\
\hline 31 & $5 \mathrm{y} / \mathrm{e}$ & - & - & $\begin{array}{l}\text { Sol po } 1 \text { kez iktal } \\
\text { aktivite+ }\end{array}$ & Sol fp fkd & 1 & $\begin{array}{l}3 \text { ilaçla } \\
\text { kontrol }\end{array}$ & - & 25 & - \\
\hline 32 & $2 \mathrm{y} / \mathrm{e}$ & + & + & $\begin{array}{l}\text { Bilateral oks 2-5 } \\
\text { sn aralarla }\end{array}$ & $\begin{array}{l}\text { Basit giral patern, beyin } \\
\text { sapi hipoplazisi }\end{array}$ & 2 & $+?$ & - & 0 & - \\
\hline 33 & $5 \mathrm{y} / \mathrm{e}$ & + & + & $\begin{array}{l}\text { Cz pozisyonunda } \\
\text { seyrek aralarla }\end{array}$ & f, p, t tuber & 1 & $\begin{array}{l}+ \\
1 \text { ilaçla } \\
\text { kontrol }\end{array}$ & TBS & 3 ay & $\begin{array}{l}\text { Yüzde } \\
\text { anjiofibromlar } \\
\text { ciltte } \\
\text { hipopigmente } \\
\text { küçük maküller }\end{array}$ \\
\hline 34 & $13 \mathrm{y} / \mathrm{k}$ & + & + & $\begin{array}{l}\text { Bilateral f 10-20 } \\
\text { sn aralarla, 1-3 } \\
\text { Hz, 1-2 sn süreli }\end{array}$ & f, p, t tuber & 1 & $\begin{array}{l}+ \\
1 \text { ilaçla } \\
\text { kontrol }\end{array}$ & TBS & 24 & $\begin{array}{l}\text { Kalpte } \\
\text { rabdomyom }\end{array}$ \\
\hline 35 & $4 \mathrm{y} / \mathrm{e}$ & + & + & $\begin{array}{l}\text { Bilateral st } 10-15 \\
\text { sn aralarla } 1-3 \\
\mathrm{~Hz}, 1-2 \text { sn süreli }\end{array}$ & f, p, t tuber & 1 & $\begin{array}{l}+ \\
1 \text { ilaçla } \\
\text { kontrol }\end{array}$ & TBS & 51 & $\begin{array}{l}\text { Bilateral } \\
\text { polikistik } \\
\text { böbrek }\end{array}$ \\
\hline 36 & $17 \mathrm{y} / \mathrm{k}$ & - & + & $\begin{array}{l}\text { Bilateral o, 5-20 } \\
\text { sn aralarla, 1-2 } \\
\text { sn süreli }\end{array}$ & Bilateral p, oks pakigri & 2 & $\begin{array}{l}+ \\
2 \text { ilaçla } \\
\text { kontrol }\end{array}$ & - & 14 & - \\
\hline
\end{tabular}

BG: bilişsel gerilik, C: cinsiyet, e: erkek, f: frontal, fkd: fokal kortikal displazi, fp: frontoparyetal, ft: frontotemporal, jen: jeneralize, $\boldsymbol{k}$ : kIz, kk: korpus kallozum, MG: motor gerilik, oks: oksipital, p: parietal, po: paryetooksipital, pv: periventriküler, sn: saniye, sp: santroparyetal, st: santrotemporal, t: temporal, TBS: tuberoskleroz, v-p: ventriküloperitoneal, y: yוl, ZS: Zellweger sendromu, WWS/MEB: walker Warburg sendromu/muscle-eyebrain, KGM sınıflama: Grup 1: megalensefali, hemimegalensefali ve tip 2 fokal kortikal displazi, Grup 2: Periventriküler heterotopi, lizensefaliler, subkortikal heterotopiler, cobblestone malformasyonlar, Grup 3: Polimikrogri ve şizensefali

Sekiz hastada (\%25) EEG klinik veya sosyal nedenlerle çekilemedi veya sonuçlara ulaşlamadı. EEG verilerine ulaşlabilen 28 hastanın 7'sinde (\%25) EEG'de patolojik bulgu saptanmadı. $\mathrm{Bu}$ yedi hastanın üçünde sadece periventriküler nodüler heterotopi mevcuttu ve herhangi bir antiepileptik ilaç kullanımı yoktu. Diğer dört hasta antiepileptik ilaç ile izlenmekteydi. EEG verisine ulașılabilen ve anormallik saptanan 21 hastanın ikisinde jeneralize deşarjlar, birinde hipsaritmi paterni ve birinde serebral disfonksiyon bulguları saptanırken 17 hastada fokal epileptik deşarjlar saptandı.

On iki hastada (\%33) tüm loblarda yaygın KGM mevcuttu (Șekil 1). 24 (\%67) hastada tek ya da iki taraflı bir ya da birden çok beyin lobunda pakigri, polimikrogri, fokal displazi ve heterotopi saptandı (Şekil 2,3,4). Fokal bulgular saptanan 24 hasta içinde; iki hastada izole periventriküler nodüler heterotopi, iki hastada izole fokal kortikal displazi saptandı. Üç hastada șizensefali mevcuttu. Tuberoskleroz tanısıly izlenen 3 hastada birçok lobda kortikal tuber mevcuttu.

Sekiz hastada (\%25) genetik testlerle tanıya ulaşlabildi (Tablo I). KGM dışında tespit edilen bulgular; üç hastada hidrosefali ve ventriküloperitoneal șant, iki hastada renal kistler, bir hastada kardiyak rabdomyom, üç hastada eşlik eden göz bulgularıydı.

\section{TARTIȘMA}

KGM ile ilişkili 20 civarı biyolojik yolak olduğu ve her bir yolağın bir ya da daha fazla gen ile bağlantılı olduğu bilinmektedir. DNA replikasyonu (ORC1, ORC4, ORC6, CDT1, CDC6 genleri), tubulinler (TUBA1A, TUBA8, TUBB2B, TUBB, TUBB3 genleri), glikolizasyon işlemleri (POMT1, POMT2, POMGNT1, POMGNT2 genleri), ekstrasellüler laminin ve aktin aktivitesi, (LAMA2, LAMB1, LAMC3, DCX, ACTB, ACTG1 genleri), MTOR işlemleri (TSC1,TSC2 genleri) bu yolaklar ve ilişkili genlere örnek verilebilir (6).

KGM sınılaması bu hasta gruplarında yeni tanımlanan genetik mutasyonlar göz önüne alınarak farklı tarihlerde yenilenmiștir. KGM, temelinde bulunan bozukluğun intrauterin dönemdeki beyin gelişiminin hangi aşamasından kaynaklandığına ve bozukluğun patogenezine göre 3 grup altında toplanabilir. Birinci grupta anormal glial ve nöronal proliferasyon veya apoptozise sekonder gelişen malformasyonlar bulunur. Mikrosefali, megalensefali, hemimegalensefali ve tip 2 fokal kortikal displazi bu grupta incelenir. İkinci grupta nöronal migrasyon anomalilerine bağlı malformasyonlar bulunur. Periventriküler heterotopi, lizensefaliler, subkortikal heterotopiler, cobblestone malformasyonlar ikinci grupta yer alır. Üçüncü grupta ise postmigrasyonel defektlere bağlı gelişen 


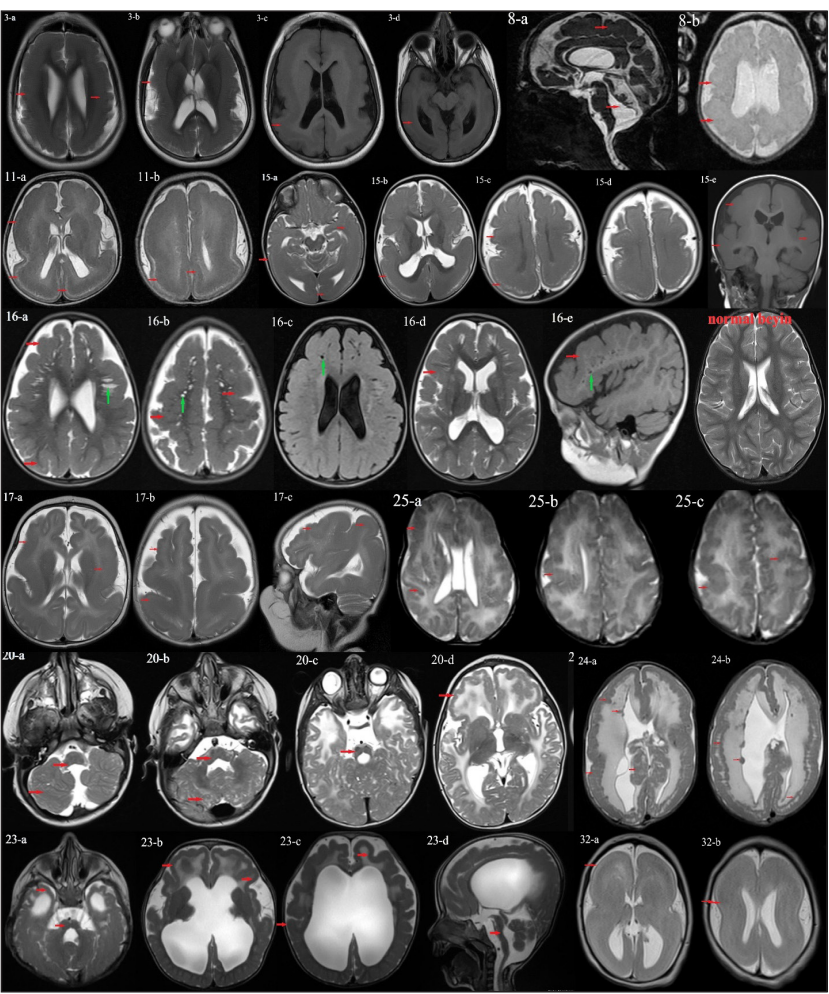

Şekil 1: Yaygın KGM saptanan hastaların MRG görüntüleri.

Hasta 3 (aksiyel T2 ve T1) , 11 (aksiyel T2), 15 (aksiyel T2 ve koronal T1), 17 (aksiyel ve sagital T2), 32'de (aksiyel T2) basit giral desen (lisensefali-pakigiri), kortikal kalınlaşma, subkortikal band heterotopi (double korteks bulgusu); hasta 8'de (aksiyel ve sagital T2) pakigiri ile uyumlu basitleşmiş giral desen, kortikal kalınlaşma, 4. ventrikülde genişleme; hasta 16'da (aksiyel T2 ve flair, sagital T1), pakigiri, kortikal kalınlaşma, belirginleşmiş perivasküler boşluklar (yeşil ok-revers tigroid desen); hasta 25'te (aksiyel T2) yaygın kortikal kalınlaşma ve perisilvian alanda belirginleşen polimikrogri; hasta 20'de (aksiyel T2) beyin sapında ince görünüm, serebellar hemisferlerde periferik mikrokistler ve polimikrogiri, serebral kortikal polimikrogiri, beyaz cevherde anormal miyelinasyon ile uyumlu T2 sinyal artışı; hasta 23'te (aksiyel ve sagital T2) beyin sapında ince görünüm, kortikal polimikrogiri, beyaz cevherde anormal miyelinasyon ile uyumlu T2 sinyal artışı, septum pellusidum yokluğu ve ventriküler dilatasyon; hasta 24'te (aksiyel T2), basitleşmiş giral desen ve yaygın polimikrogiri (kaldıım taşı lizensefali), beyaz cevherde anormal miyelinasyon ile uyumlu sinyal artışı, subependimal gri cevher heterotopileri izlenmektedir.

malformasyonlar bulunur. Polimikrogri ve şizensefali, tip 1 fokal kortikal displaziler üçüncü grup altında incelenir $(3,10)$. Bu çalışmada, bazı hastalarda yukarıdaki sınılamaya göre iki farklı gruptan malformasyon bulunması ve fokal kortikal displazilerin kesin olarak tiplendirmesinin histopatolojik olarak yapilabilmesi nedeniyle hastalar bu sinflamaya göre sadece tabloda gruplandırımışıır. Bu nedenle hastalar esas olarak görüntüleme sonuçlarına göre tüm beyin loblarını içeren yaygın tutulumlu olanlar ve bir ya da birkaç loba sınırlı fokal ve bölgesel tutulumlu olanlar şeklinde ayrılarak sınıflandırımıştır. Hastaların \%33'ünde yaygın KGM; \%67'sinde fokal KGM tespit edildi.

KGM perinatal dönemde çoğunlukla bulgu vermezler. Küçük bir kısmında polihidroamnios doğumdan sonraki ilk günlerde hipotoni, emmede azalma ve nöbet olabilir. Çoğunlukla

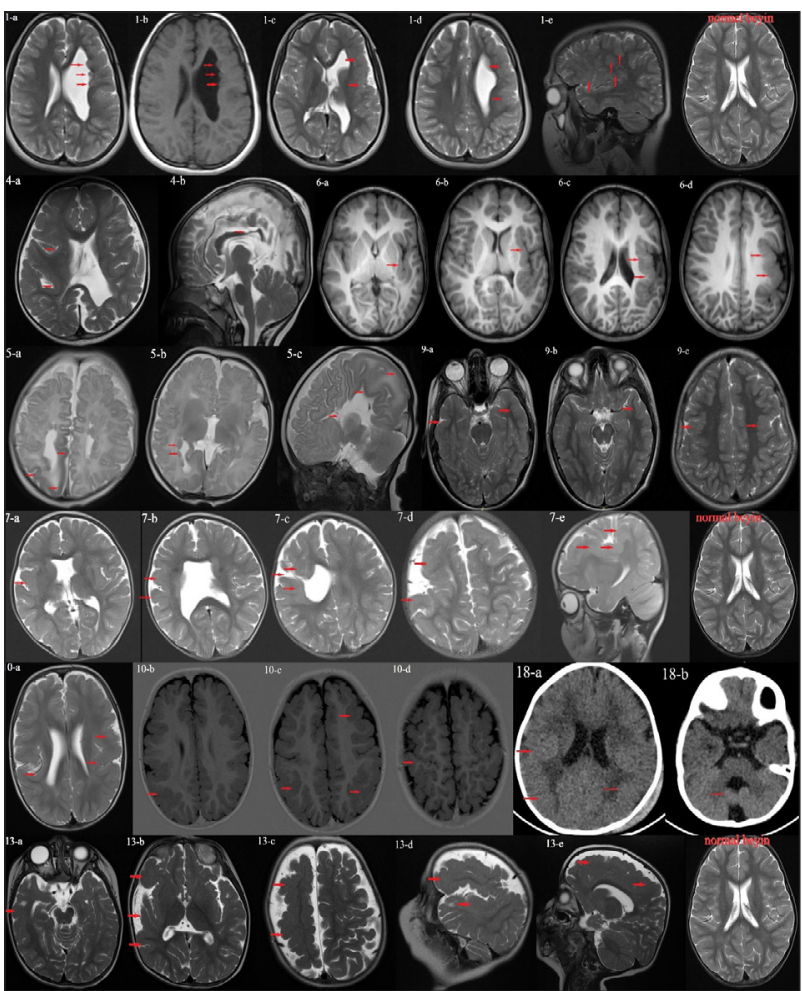

Şekil 2: Tek ya da iki taraflı bir ya da birden çok beyin lobunda KGM saptanan hastaların görüntüleme bulguları.

Hasta 1'de (aksiyel T1 ve T2 ve sagital T2) sol periventriküler nodüler heterotopi ve sol frontal ve paryetal lobları içeren polimikrogrik alanlar; hasta 4'te (aksiyel ve sagital T2) sağ perisilvian kortikal kalınlaşma; hasta 6'da (aksiyel T1) sol insüler ve perisilvian alanda polimikrogri; hasta 5'te (aksiyel ve sagital T2) sağ oksipital kortikal kalınlaşma, gribeyaz cevher ayrımında silinme, eşlik eden periventriküler heterotopi ve korpus kallozum agenezisi; hasta 9'da (aksiyel T2) bilateral temporal ve perisilvian polimkrogri; hasta 7'de (aksiyel ve sagital T2) sağ frontoparyetal bileșkede șizensefali ve eșlik eden pakigiri; hasta 10'da (aksiyel T1 ve T2) bilateral frontal, paryetal ve oksipital loblarda polimikrogrik korteks görünümü, hasta 18'de (aksiyel tomografi) bilateral paryetooksipital kortikal kalınlașma ve vermis hipoplazisi, hasta 13'te (aksiyel ve sagital T2) sağ hemisfer frontal, temporal ve paryetal loblarda polimikrogri izlenmektedir.

malformasyonun şiddetine, eșlik eden diğer organ tutulumlarına göre değişken olarak yașamın illk yllından bașlayarak ileri yaşlara kadar uzanan bir dönemde hipotoni, motor ve bilişsel becerilerde gerilik, nöbetler ile bulgu verirler. Altta yatan etyolojiye göre değişkenlik gösteren diğer organ tutulumlarına bağı bulgular görülebilir $(6,7)$. Mikrosefali, çeşitli göz bulguları, hidrosefali, renal kistler, kardiyak rabdomiyom, cilt lekeleri bizim hasta grubumuzda eșlik eden bulgular arasındaydı.

Motor ve bilișsel alanda çeșitli derecelerde gerilikler, KGM'u olan hastaların en sık başvuru șikâyetlerindendir (4). En sık görülen temel nedenler arasında olan motor ve bilișsel becerilerde gerilik ve nöbet dıșı nedenlerle; baş ağrısı ve baș dönmesi nedeniyle başvuran iki hastada izole periventriküler nodüler heterotopi mevcuttu. Yaygın ve tüm lobları içeren KGM'u olan 12 hastanın 


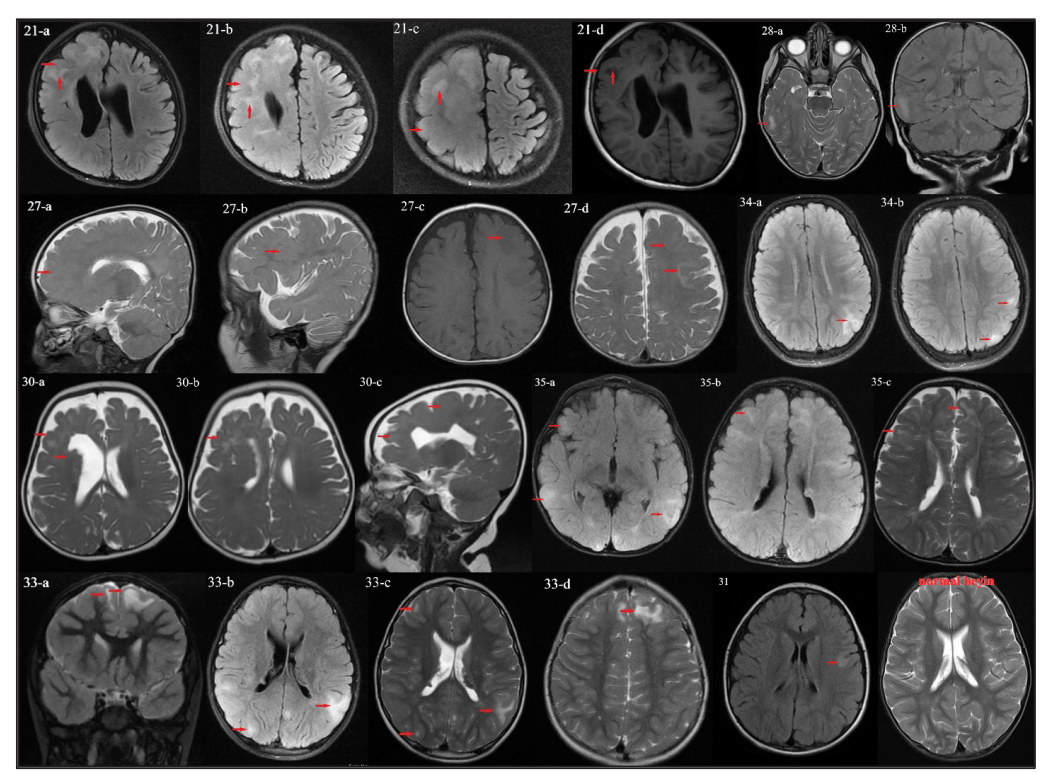

Şekil 3: Tek ya da iki taraflı bir ya da birden çok beyin lobunda KGM saptanan hastaların görüntüleme bulguları.

Hasta 21 (aksiyel T2 ve T1) ve 30'da (aksiyel ve sagital T2) sol, hasta 27'de (sagital T2, aksiyel T1 ve T2) sağ frontal ve parietal loblarda kortikal kalınlaşma ve düzensizliğe eşlik eden subkortikal beyaz cevher hiperintensitesi fokal kortikal displazi görünümüne uymaktadır. Hasta 28 (aksiyel T2 ve koronal flair) ve 31'de (aksiyel flair) sırasıyla sağ temporal ve sol frontoparyetal bileşkede sınırlı fokal kortikal displazi alanları görülmektedir. Tuberoskleroz tanilı hasta 33 (koronal T2 ve aksiyel flair, T2), 34 (aksiyel flair), 35’te (aksiyel flair ve T2) birden çok lobda kortikal tuberler dikkati çekmektedir.

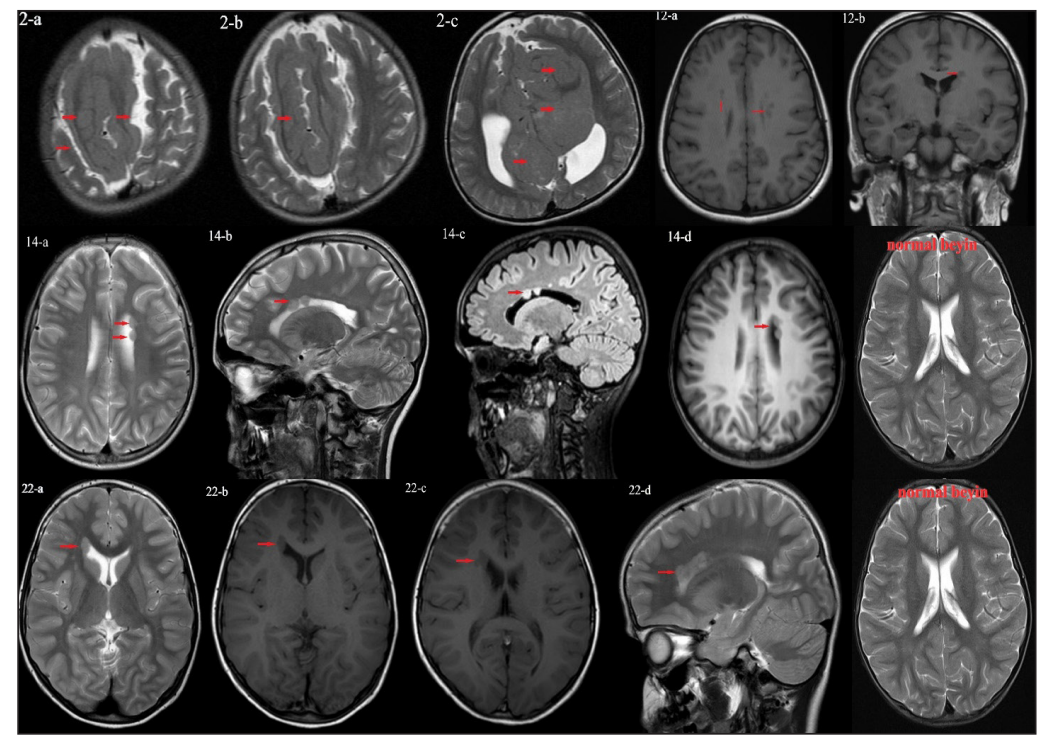

Şekil 4: Tek ya da iki taraflı bir ya da birden çok beyin lobunda KGM saptanan hastaların görüntüleme bulguları

Hasta 2'de (aksiyel T2) bilateral şizensefal v.e dev giriform heterotopi (beyin içinde beyin görünümü), hasta 12 (aksiyel koronal T1), 14 (aksiyel ve sagital T2 ve flair, aksiyel T1), 22'de (aksiyel T2 ve T1) periventriküler nodüler heterotopi alanları izlenmektedir.

tümünde (\%100) hem motor hem bilișsel becerilerde değişik șiddetlerde gerilik mevcuttu. Tüm lobları içermeyen bir ya da birkaç lobda KGM'u olan 24 hastanın 14'ünde (\%58) motor becerilerde, 16'sında (\%66) bilişsel becerilerde farklı şiddetlerde gerilik saptandı.

Nöbetler, KGM'u olan hastaların bașvuru anında ya da takibinde ortaya çıkan temel bulgulardan biridir. Dirençli epilepsi olan hastaların \%40'ında KGM olduğunu bildiren çalışmalar mevcuttur $(8,9)$. Takip süresi içinde 36 hastamızın 26'sında (\%72) nöbet olduğu görüldü. Yaygın ve tüm lobları içeren KGM'u olan beş hastanın daha önceki öyküsünde ve takip süresi içinde nöbeti yoktu. Tüm lobları içermeyen bir ya da birkaç lobda KGM'u olan hastaların \%78'inde nöbetler mevcutken \%22'sinde takip süresince nöbet görülmedi. Epilepsi olan hastalar içinde kullanılan ve hasta başına düşen ortalama ilaç sayısı 1.2'di. Iki grupta istatistiksel olarak değerlendirilebilecek kadar yeterli hasta sayısına ulaşılamadığı düşünüldüğünden mevcut farklar yüzdelik oranlar olarak verildi.
EEG verilerine ulaşılabilen 28 hastanın yedisinde (\%25) anormallik saptanmamıştır. Normal EEG'si olan hastaların bir kısmında izole periventriküler nodüler heterotopi mevcutken bir kısmında ise yaygın KGM'u mevcuttu. Bazı hastalarda yaygın KGM'u olmasına rağmen EEG patolojisi bulunmamasının bir kısmında ilaç kullanımı nedeniyle ortaya çıkan baskılanmaya bağlı olabileceği düşünülmüştür. Rutin bir uyanık ve/veya uyku EEG çekimi ile bir hastanın 24 saatlik bir günü içinde rastgele 30 dakikalık beyin dalga aktivitesinin kayıt altına alındığı dikkate alınacak olursa bu hastalarda olası aralıklı epileptik deşarjların varlığını saptayabilmek için uzun süreli EEG monitörizasyonlarına intiyaç olduğu unutulmamalıdır.

KGM'de çoğunlukla nöbet, motor ve bilişsel gerilik bulgularıyla gelen hastalarda yapılan beyin görüntülemeleri ile tanıya ulaşılır. Beyin MRG tekniklerindeki gelişmeler sayesinde çözünürlüğü yüksek beyin görüntülemeleri elde edilmekte ve mevcut KGM daha yüksek oranlarda yakalanabilmektedir (10). Normal 
beyinde girusların çoğu $1-1.5 \mathrm{~cm}$ genişlikte ve korteks 3-4 $\mathrm{mm}$ kalınlığındadır. Lizensefalisi olan bir hastada ise girusların genişliği $3 \mathrm{~cm}$ ya da daha genişlikte olup korteks kalınlığı 8-20 mm arasında değişmektedir (6). Bu çalışmadaki tüm hastaların KGM tanısına radyolojik görüntüleme yöntemleriyle ulaşımıştır.

Nöbet, motor ve/veya bilişsel gerilik şikâyetlerinden bir veya birkaçının bir arada bulunduğu klinik tabloyla başvuran çocuklarda santral sinir sistemi, periferik sinir sistemi, kassinir kavşağı ve kaslar dâhil olmak üzere birçok yapıda yapısal, konjenital, metabolik ve genetik anormallikler aranmaktadır. KGM'u saptanan hastalarda tam bir fizik muayene ile eşlik edebilecek mikrosefali, makrosefali, göz anormallikleri (korneal bulanıkık, katarakt, mikroftalmi, kırma kusurları, retinitis pigmentosa, retinit bulguları), dismorfik bulgular, cilt lekeleri, spina bifida, anjiofibromlar dikkatlice gözden geçirilmelidir. Diğer organ görüntüleme yöntemleriyle kardiyak inceleme ve batın içi solid organların incelenmesi bazı hastalarda tanı koydurucu olabilir. Renal kistleri olan bir hastada tuberoskleroz, zellweger sendromu olası tanilar arasında yer alırken, kardiyak rabdomiyom saptanan bir hastada tuberoskleroz ilk sıradaki tanı olabilir. Motor geriliğe eşlik eden nöbetler ve kreatin kinaz yüksekliği olan hastalarda konjenital müsküler distrofiler; intrakranial kalsifikasyonları, beyaz cevherde dismiyelinizasyon ve retinit bulguları olan bir hastada konjenital CMV enfeksiyonları düşünülmelidir.

MRG bu hastalarda ilk başvurulan tanı yöntemlerinden biridir. Beyin MRG'de saptanan KGM'nin tipi, yaygınlığı eşlik eden diğer beyin yapılarının tutulumu (beyaz cevher, bazal ganglionlar, korpus kallozum, serebellum), kalsifikasyon varlığı olası tanılar açısından birçok ipucu verebilmektedir. Yaygın lizensefali, agiri, pakigri ve subkortikal band heterotopi (double korteks) saptanan hastalarda LIS1, DCX, TUBA1A, ARX ve RELN gen mutasyonları en sık nedenler arasındadır. Yaygın cobble-stone malformasyon saptanan hastalarda korteks nodüler görünümlüdür ve genellikle eşlik eden kreatin kinaz yüksekliği, beyaz cevherde yaygın dismiyelinizasyon, beyin sapı ve serebellum hipoplazisi ve göz anomalileri ile fukuyama müsküler distrofi, muscleeye-brain hastalığı ve walker-warburg sendromu (FKRP, POMGNT1, POMT1, POMT2, LAMA1 gen mutasyonları) olası tanılar içinde bulunur (10). Bu çalışmada genetik mutasyonu gösterilen sekiz hastanın yarısında saptanmış olan mutasyonlar konjenital müsküler distrofi ile ilşkiliydi. GPR56 geninde ve PAFAH1B1 geninde saptanan mutasyonlar ve bu genlerin KGM'u ile bağlantısı daha önce tanımlanmışıı (10). SRPX2 geninde mutasyon saptanan hastaların rolandik epilepsi, mental retardasyon ve konuşma bozuklukları ile başvurduğu ve bu hastalar içinde beyin MRG'de perisilvian polimikrogri saptanan hastalar olduğu bildirilmiştir (11). Bir hastamızda saptanmış olan PEX1 mutasyonu Zellweger sendromu ile ilşkiliydi ve hastada çok uzun zincirli yağ asitlerinde artış, dismorfik bulgular, renal kistler mevcuttu.

\section{SONUÇ}

Nöbet, motor ve bilişsel gerilik şikâyetlerinin bir ya da birkaçının bir arada olduğu tablo ile başvuran hastalarda oldukça geniş bir etyoloji bulunmaktadır. İnce kesitli, 1.5 Teslanın üzerinde çözünürlükte yapılan bir beyin MRG ile saptanabilecek KGM durumunda genetik, enfeksiyöz, metabolik ve nöromüsküler nedenler aranmalıdır. KGM'nin morfolojik tiplendirmesi, yaygınlığı, eşlik eden diğer beyin yapılarındaki anormallikler oldukça yol göstericidir. Tam fizik muayene ve diğer organ incelemeleri olası etyolojik yelpazeyi daraltabilir. Genetik testlerdeki gelişmeler ve kullanımındaki yaygınlık arttıkça KGM'u olan hastalarda bilinen genetik mutasyonların saptanması ile hem kesin tanıya ulaşmak kolaylaşacaktır hem de daha önce sorumlu mutasyonu bilinmeyen hastalarda yeni mutasyonların bulunması mümkün olacaktır.

\section{KAYNAKLAR}

1. Barkovich AJ, Kuzniecky RI, Dobyns WB, Jackson GD, Becker LE, Evrard P. A classification scheme for malformations of cortical development. Neuropediatrics 1996;27:59-63.

2. Raybaud C, Widjaja E. Development and dysgenesis of the cerebral cortex: malformations of cortical development. Neuroimaging Clin N Am 2011;21:483-543, vii.

3. Barkovich AJ, Guerrini R, Kuzniecky RI, Jackson GD, Dobyns WB. A developmental and genetic classification for malformations of cortical development: update 2012. Brain 2012;135:1348-69.

4. Severino M, Geraldo AF, Utz N, Tortora D, Pogledic I, Klonowski W, et al. Definitions and classification of malformations of cortical development: practical guidelines. Brain 2020;143:2874-94.

5. LoTurco JJ, Booker AB. Chapter 26-Neuronal Migration Disorders. In: Rubenstein JLR, Rakic P, editors. Cellular Migration and Formation of Neuronal Connections. Oxford: Academic Press 2013:481-94.

6. Dobyns WB, Leventer RJ, Guerrini R. Malformations of Cortical Development. In: Swaiman KF, editor. Swaiman's Pediatric Neurology 2018:520-49.

7. Naumburg E, Strömberg B, Kieler H. Prenatal characteristics of infants with a neuronal migration disorder: a national-based study. Int J Pediatr 2012;2012:541892.

8. Kuzniecky RI. Magnetic resonance imaging in developmental disorders of the cerebral cortex. Epilepsia 1994;35 Suppl 6:S4456.

9. Pasquier B, Péoc HM, Fabre-Bocquentin B, Bensaadi L, Pasquier D, Hoffmann D, et al. Surgical pathology of drug-resistant partial epilepsy. A 10-year-experience with a series of 327 consecutive resections. Epileptic Disord 2002;4:99-119.

10. Lee J. Malformations of cortical development: genetic mechanisms and diagnostic approach. Korean J Pediatr 2017;60:1-9.

11. Roll P, Rudolf G, Pereira S, Royer B, Scheffer IE, Massacrier A, et al. SRPX2 mutations in disorders of language cortex and cognition. Human Molecular Genetics 2006;15:1195-207. 